\title{
Utilização da técnica microbiológica convencional, Reação em Cad eia pela Polimerase (PCR) e ensaio imunoenzimático (ELISA) no monitoramento de Salmonellaem carcaças de frango para o controle higiênico-sanitário do processo de abate*
}

\author{
ELCI LOTAR DICKEL
}

\author{
Vladimir Pinheiro do Nascimento (Orientador - UFRGS)
}

\author{
Banca: Paulo Soares da Costa (UFF), Maristela Lovato Flores (UFSM), Guiomar Pedro Bergmann (UFRGS)
}

\begin{abstract}
O presente estudo teve como objetivo realizar uma análise comparativa das técnicas de Reação em Cadeia pela Polimerase (PCR) e Ensaio Imunoenzimático (ELISA - SALVIA ${ }^{\circledR}$ ) com o método microbiológico convencional para detecção de Salmonella Enteritidis (SE), S. Typhimurium (ST), S. Gallinarum(SG) e S. Pullorum (SP) em carne de frango. As amostras foram contaminadas artificialmente com diluições de $10^{-7}, 10^{-8}$ e $10^{-9}$ para SE e ST e de $10^{-4}, 10^{-5}$ e $10^{-6}$ para SG e SP, com cinco repetições de cada diluição, totalizando 300 análises. Os testes foram realizados em cinco diferentes laboratórios para a validação das técnicas. Na avaliação geral dos dados obtidos, a microbiológica convencional obteve 56,67\% (170/300) de recuperação das amostras contaminadas por Salmonella artificialmente, enquanto que as técnicas de ELISA e PCR representaram 71\% (213/300) e 75\% (225/300), respectivamente. A análise dos resultados de detecção de Salmonella através dos testes ELISA e PCR, em relação ao microbiológico convencional, apresentaram diferença estatística ( $\mathrm{p}=0,0001$, teste de MacNemar). Não houve diferença significativa entre os resultados da PCR e do ELISA. Após essa etapa do trabalho, as três técnicas também foram testadas a campo, na qual foram utilizadas três categorias de matadouros: um com abate totalmente automatizado (ATA) e dois com abate semi automatizado, sendo um de grande porte (ASAGP) e outro com pequeno porte (ASAPP). Em todos os matadouros as coletas foram realizadas obedecendo a mesma metodologia, utilizandose os seguintes procedimentos: em cada matadouro foram coletadas amostras de 20 lotes, distribuídos em 20 pools de suabes cloacais de 100 aves, 20 carcaças de frango após a evisceração e antes do chiller e 20 carcaças de frango após o chiller, totalizando 60 lotes e 180 amostras. A metodologia das análises foi a mesma empregada na etapa anterior. Os resultados mostraram que, na microbiologia convencional (MC) foram isoladas 47/180 amostras positivas (26\%), ELISA 32/ 180 (17,8\%) e PCR 22/180 (12,2\%). Houve diferença estatística significativa entre as três técnicas, sendo que a MC apresentou eficácia superior $(\mathrm{p}=0,05)$ na detecção de Salmonella em relação as demais técnicas. Nessa etapa também foi investigada a presença de Salmonella em diferentes etapas do processamento industrial das três categorias de matadouro avícola. No matadouro com tecnologia totalmente automatizada foram identificadas 30/60 (50\%) amostras positivas para Salmonella, sendo 12/20 (60\%) no suabe cloacal, 14/20 (70\%) antes do chiller e 4/20 (20\%) após o chiller. No matadouro com tecnologia semi-automatizada, 4/20 (20\%) amostras foram positivas no suabe cloacal, $5 / 20$ (25\%) antes do chiller e 8/20 (40\%) após o chiller, totalizando 17/60 (28,3\%) amostras positivas, enquanto que no matadouro com tecnologia manual não houve isolamento de Salmonella. Das 180 amostras analisadas, isolou-se Salmonella em 47 (26,11\%), das quais 63,9\% (30/47) foram $S$. Heidelberg, 31,9\% (15/47) S. Enteritidis, 2,1\% (1/47) S. Worthington e 2,1\% (1/47) S. Tennessee.
\end{abstract}

Descritores: Salmonella, carcaças de frango, microbiologia convencional, PCR, ELISA, tecnologia de abate

Apresentada: 20 fevereiro 2004

*Tese de Doutorado n. 39 (Especialidade: Sanidade Avícola). 138f. Programa de Pós-graduação em Ciências Veterinárias da Faculdade de Veterinária - UFRGS, Porto Alegre/RS. CORRESPONDÊNCIA: E.L. Dickel [elcidickel@upf.tche.br]. 


\title{
The use of the conventional microbiological technique, polymerase chain reaction (PCR) and enzyme linked immunosorbent assay (ELISA) in monitoring salmonella in broiler carcasses for the sanitary control in the slaughtering process**
}

\author{
ELCI LOTAR DICKEL \\ Vladimir Pinheiro do Nascimento (Adviser - UFRGS) \\ Committee: Paulo Soares da Costa (UFF), Maristela Lovato Flores (UFSM), Guiomar Pedro Bergmann (UFRGS)
}

The present study aimed at comparatively analysing the techniques of Polymerase Chain Reaction (PCR), Enzyme Linked Immunosorbent Assay (ELISA - SALVIA ${ }^{\circledR}$ ) and Conventional Microbiology for detecting Salmonella Enteritidis (SE), S. Typhimurium (ST), $S$. Gallinarum (SG) and $S$. Pullorum (SP) in broiler meat. The samples were artificially contaminated with serial dilutions of $10^{-7}, 10^{-8}$ and $10^{-9}$ for SE and ST and of $10^{-4}, 10^{-5}$ e $10^{-6}$ for SG and SP, with five replications of each dilution, in a total of 300 analysis. In order to validate the techniques, the tests were performed in five different laboratories. The general evaluation of the obtained data indicated that the conventional microbiology was able to detect 56,67\% (170/300) of the Salmonella artificially contaminated samples, while the ELISA and the PCR techniques detected respectively $71 \%$ (213/300) and 75\% (225/300). When analyzing the above results, the ELISA and PCR demonstrated a significant statistical difference $(\mathrm{P}=0,0001, \mathrm{McNemar}$ Statistical Test) over the conventional microbiology. There was no significant difference between the ELISA and the PCR results. After this first stage, the three techniques were also field tested, where three classes of abattoirs were tested: one with fully automated process (ATA), and the other two with semi-automated slaughter, being one of large size (ASAGP) and the other one of small size (ASAPP). In all the abattoirs the samples were collected by the same method, as follows: in each abattoir samples were collected from 20 broiler lots, distributed in cloacal swabs (CS) from 100 broilers, divided in 20 pools of 5 CS each; 20 carcasses after evisceration and before the chiller, and finally 20 carcasses after the chiller, in a total of 60 broiler lots and 180 samples. The analysis method was the same used in the previous stage. Results showed that, in the conventional microbiology (CM) 47 positive samples out of 180 were isolated (26\%), while the ELISA detected 32/180 (17,8\%) and the PCR 22/180 (12,2\%). There was a significant statistical difference between the three techniques, with the CM presenting a superior efficacy $(\mathrm{P}=0,05)$ in detecting Salmonella when compared to the other techniques. At this stage, the presence of Salmonella in different industrial processing steps of the three broiler slaughtering plants was also investigated. In the fully automated plant, 30 out of 60 samples (50\%) were Salmonella positively identified, being 12/20 (60\%) in cloacal swabs, 14/20 (70\%) before the chiller and $4 / 20(20 \%)$ after the chiller. In the large semi-automated abattoir, 4/20 (20\%) of cloacal swab samples were positive, while 5/ $20(25 \%)$ before the chiller and 8/20 (40\%) after the chiller were detected, giving a total of 17 out of $60(28,3 \%)$ tested samples. There was no Salmonella isolation in the small size fully manual abattoir. Finally, among the 180 analysed samples, Salmonella was isolated in 47 (26,11\%) from which 63,9\% (30/47) were $S$. Heidelberg, 31,9\% (15/47) were $S$. Enteritidis, 2,1\% (1/47) $S$. Worthington and $2,1 \%(1 / 47) S$. Tennessee.

Key words: Salmonella, Broiler carcasses, Conventional microbiology, PCR, ELISA, Slaughter technology.

Presented: 20 February 2004

**Doctoral Dissertation \# 39 (Field: Avian Pathology). 138p. Graduate Program in Veterinary Sciences, Faculdade de Veterinária, Universidade Federal do Rio Grande do Sul (UFRGS), Porto Alegre/Brazil. CORRESPONDENCE: E.L. Dickel [elcidickel@upf.tche.br]. 